\title{
LEXICON
}

Volume 7, Number 2 (October 2020)

Pages 215-223

https://jurnal.ugm.ac.id/lexicon

https://doi.org/10.22146/lexicon.v7i2.66571

\section{Impoliteness Strategies in Trevor Noah's Afraid of the Dark Stand-up Comedy Show}

\author{
Aulia Hafisa, Sharifah Hanidar* \\ English Department, Universitas Gadjah Mada, Indonesia \\ *Corresponding Author: sharifah@ugm.ac.id
}

\begin{abstract}
This research focuses on identifying the impoliteness strategies and explaining the purposes of the most frequently used strategy in Afraid of the Dark stand-up comedy show performed by Trevor Noah. It also aims at analyzing Trevor Noah's utterances that use impoliteness strategies proposed by Jonathan Culpeper (1996). The result of this research indicates that Trevor Noah uses 105 instances of impoliteness strategies which cover all five types of strategies proposed by Culpeper; bald on record impoliteness, positive impoliteness, negative impoliteness, sarcasm or mock politeness, and withhold politeness. It also conveys that negative impoliteness is the most frequently used strategy. It occurs 42 times or with a percentage of $40 \%$ of the whole data. It is used by Trevor Noah as a device to entertain the audience. He mostly used 'condescend, scorn, or ridicule' sub-strategies of negative impoliteness to induce laughter and amuse the audience by giving them the enjoyment of hearing one being ridiculed or condescended.
\end{abstract}

Keywords: impoliteness strategies, stand-up comedy, utterances, entertainment.

\section{INTRODUCTION}

In social interaction, people should apply politeness strategies. It is a sign of respect and expression of what people feel for others in apologies, compliments, greetings, or thanks (Schwarz, 2010). Brown and Levinson (1987) state that politeness should be understood as a strategic conflict avoidance or the strategy to maintain public self-image when it is attacked.

Besides politeness, there is an opposite phenomenon called impoliteness. While politeness maintains to avoid conflict, impoliteness maintains to attack face which causes social conflict and disharmony (Culpeper, 1996). There are three functions of impoliteness classified by Culpeper (2011) which are affective, coercive, and entertaining.

For entertaining purposes, Culpeper (2011) points out that impoliteness is often used in comedy in order to amuse others. Generally, impoliteness promotes social conflicts and disharmony. However, the fact that people can be entertained by impoliteness such as symbolic violations to identity and social rights is not surprising (Culpeper, 2011).

Stand-up comedy is one kind of entertainment performed by one person, called comic or stand-up comedian, standing on the stage speaking directly to the audience (Schwarz, 2010). Stand-up comedians often involve their audience by using impoliteness 
strategies such as criticizing, mocking, or insulting them. Although the audience's face is "attacked", they are not offended and appraise it as humorous.

This research focuses on Trevor Noah, a South African stand-up comedian, who is the host of The Daily Show, an American satirical news program. One of his best show is entitled Afraid of The Dark performed in 2017. In this show, Trevor creates humor by using impoliteness strategies to entertain the audience. This research also aims to identify the impoliteness strategies used by Trevor Noah and explain the reasons for which he used condescend, scorn or ridicule more than the other sub-strategies in his performance. This research aims to identify the impoliteness strategies used by Trevor Noah and explain the reasons for which he used condescend, scorn or ridicule more than the other sub-strategies in his performance in Afraid of The Dark stand-up comedy show.

\section{LITERATURE REVIEW}

There have been several researches that address impoliteness and politeness strategies used in films, television shows and stand-up comedy.

Rosa (2017) in her research entitled "Impoliteness Strategies in the film The Fault in Our Star" focuses on the counter strategies used by the characters to respond to the impoliteness strategy, and the effect of power level difference in the use of impoliteness strategy.

An article on a similar topic entitled "Impoliteness Strategies Based on Culpeper's Model: An analysis of Gender Differences between Two Characters in the movie Mother" was written by Mirhosseini, Mardanshahi, and Dowlatabadi (2017). Using Culpeper's model to analyse the types of strategy, the research examines eight extracts of the movie. The findings indicate that the male unlike the female characters used all Culpeper's impoliteness strategies in their interactions. It is found that the male characters used all Culpeper's super-strategies with a total number of 58 occurrences. However, the research reveals that the application of Culpeper's theory is not comprehensive enough because one cannot draw a clear-cut border between Culpeper's impoliteness strategies since one strategy overlaps another. Moreover, the significant impact of intonation and self-insulting has been ignored in Culpeper's model.

Another research related to impoliteness and humour was done by Uçar\& Yildiz (2015) entitled Humour and Impoliteness in Turkish: A corpusbased analysis of the television show Komedi Dükkânı 'Comedy Shop'. This research examines different types of impoliteness strategies applied in the Turkish television show Komedi Dukkani "Comedy Shop," which is a new kind of hunor genre, a folk theatre in traditional Turkish folk drama by using Culpeper's framework of impoliteness.

Another research conducted by Kurniawan (2015) is entitled Politeness Strategies in Russell Peters Red, White and Brown Stand-up Comedy Show which focuses on stand-up comedy. The research analyses in depth the politeness strategies used by Russel Peters.

The last research related to stand-up comedy and humour was carried out by Jeannine Schwarz in her dissertation entitled Linguistic Aspects of Verbal Humour in Stand-up Comedy (2010). The main focus of the research is the way successful stand-up comedians organize and perform the materials in order to create humour, elicit laughter, and make the audience appreciate the comic's performances.

The previous researches have several similarities. It is apparent that Rosa, Mirosseni, and Aygül Uçar, use the same theory which is Culpeper's theory to classify and analyse the data. The present research also uses the same theory as that used by the previous researchers; however, the difference lies in the object of the research, stand-up comedy show and the focus of analysis is impoliteness. Therefore, it may be affirmed that the topic of the present research is different from that of the previous researches. However, the aforementioned researches are used as references.

\section{THEORETICAL FRAMEWORK}

The research is based on impoliteness theory in pragmatics study. Levinson (1983) defines that pragmatics is the study of language use. It is basic to an account of language understanding which 
involves the making of inferences that will connect what is said to what is mutually assumed or what has been said before. In this study, people try to see the relationship between language and contexts. Context is a background knowledge that is shared by the speaker and the hearer in understanding their utterances (Cutting, 2002).

In studying linguistic impoliteness, the term face is a central concept. Brown \& Levinson (1987) define a face as an individual's feeling of self-worth or self-image, reputation, or good names that everyone has and expects everyone else to recognize. They further state that face consists of two related aspects which are; positive face as the positive consistent self-image or 'personality' (crucially including the desire that self-image be appreciated and approved of), and negative face as the basic claim to territories, personal preserves, rights to nondistraction, i.e. to freedom of action and freedom from imposition.

Face or self-image can be damaged or maintained. To maintain the face, Brown and Levinson introduce the concept of politeness theory that should be understood as a strategy of conflict avoidance to maintain public self-image when it is attacked (1987).

There are other times when people attack face or strengthen the face threat of an act. This is called impoliteness. The first scholar to mention impoliteness is Culpeper. He uses the term impoliteness to refer to "communicative strategies designed to attack face, and thereby cause social conflict and disharmony" (Culpeper, 1996). Impoliteness comes about when: 1) the speaker communicates face-attack intentionally, or 2) the hearer perceives and/or constructs behavior as intentionally face-attacking, or 3) a combination of 1) and 2) (Culpeper, 2005).

Culpeper (1996) divides impoliteness strategies into five types, each of which is discussed below.

\section{Bald on Record Impoliteness}

Bald on record impoliteness is a strategy tha is used by people to deliberately attack someone's face. Culpeper (1996) states that bald on record impoliteness is usually performed unambiguously and concisely. This strategy is often used by the speaker who has a close social distance with the hearer or the speaker who has higher power over the hearer.

\section{Positive Impoliteness}

Positive impoliteness is a strategy designed to damage the addressee's positive face wants. Culpeper (1996) suggested that positive impoliteness can be performed in various ways, such as (1) ignore, snub the others, (2) exclude the others from an activity, (3) disassociate from the other, (4) be disinterested, unconcerned; unsympathetic, (5) use inappropriate identity marker, (6) use obscure or secretive language, (7) seek disagreement (8) make others feel uncomfortable, (9) use taboo words, and (10) call the other names.

\section{Negative Impoliteness}

Negative impoliteness is the use of strategies to damage the addressee's negative face wants. This strategy is used because the speaker wants freedom in doing something. Culpeper (1996) mentions five sub-strategies which are considered to be negative impoliteness; (1) frightened, (2) condescend, scorn or ridicule, (3) invade the other's space, (4) explicitly associate the other with a negative aspect, and (5) put the other's indebtedness on record.

\section{Sarcasm or Mock Politeness}

Another type of strategy described by Culpeper is sarcasm or mock politeness. Sarcasm is a facethreatening act that is performed through the employment of politeness strategy insincerely (Culpeper, 1996). In this strategy, a politeness act is used but the meaning is not true (Culpeper, 2005). Sarcasm can be used to express the opposite of how people feel toward others.

\section{Withhold Politeness}

The last strategy stated by Culpeper is withholding politeness. This strategy happens when there is no response from the speaker when politeness expression is expected (Culpeper, 1996). Being silent and failing to thank are examples of this strategy.

According to Culpeper (2011), the impoliteness strategy has three functions. They are 
affective impoliteness, coercive impoliteness, and entertaining impoliteness. The affective function is intended to make emotional outbursts from the addressee as the output. Then, coercive impoliteness is aimed to seek a rearrangement of values between the speaker and the addressee in which the speaker gets more advantage or get current benefits protected (Culpeper, 2011). Entertaining impoliteness exploits the target or potential target of impoliteness which includes entertainment at their cost (Culpeper, 2011).

\section{Stand-up Comedy}

Stand-up comedy is one form of humor performed by one person, called comic or stand-up comedian, standing on the stage speaking directly to the audience (Schwarz, 2010). The way stand-up comedians make the audience laugh, according to Schwarz (2010), is by telling a succession of funny stories, one-liners or short jokes, and anecdotes, which are often called "bits". Some of the topics delivered by the stand-up comedians are about ideology, politics, ethnicity, and other popular issues (Glick, 2007).

\section{METHODS}

\section{Method of Data Collection}

The data source of the research is the stand-up comedy show entitled Afraid of the Dark which was accessed legally from a streaming service called Netflix (https://www.netflix.com/). The data of this research are the impoliteness strategies used by Trevor Noah in Afraid of the Dark stand-up comedy show. The researchers used the script to get accurate data. It is freely downloaded from https://www.scripts.com/script/trevor_noah_afraid_ of_the_dark.

To collect the data, the researchers watched Afraid of the Dark show to verify that the script corresponds to the utterances made by Trevor Noah. The next step is to note down the utterances containing the impoliteness strategies. The third step is reselecting the data to determine the validity of the data. Then, the researchers formulate the format of the data, including the coding system. The data presented in the analysis are written as follows:

(1) $\quad 00: 20: 16-00: 20: 54$

\section{An Indian coming to Britain}

1 TN: I don't understand why British people are complaining, going, [why are they coming here? why the hell are you coming here?!] $]^{\mathrm{BR}}$

2 [Because you told us how great it was, so we came to see for ourselves] $]^{\text {IN }}$

3 AU: ((Laughter))

\{Applause\}.

4 TN: [No. Go back to where you came from! Go back! You're not welcome here. This is not your home] $]^{\text {BR }}$

$5 \quad$ But you said we are all part of the British Empire] $]^{\mathrm{IN}}$

6 [When I said 'part,' I meant you are under us. $\mathrm{We}$ are the British. You are the empire] $]^{\mathrm{BR}}$

7 [Okay, well, in that case, the empire strikes back $]^{\mathrm{IN}}$

8 AU: ((Laughter))

\{Applause\}

In the example above, '00:20:16-00:20:54' shows the time stamp which indicates the exact time of the scene that appears in the show. 'TN' is the abbreviation for Trevor Noah and 'AU' is the abbreviation for the audience. Number 1-8 shows the order of the utterances in the extract. The bold sentence indicates the impoliteness strategy performed in the extract. The superscripted codes BR and IN indicate accents that Trevor imitated in the extract (see Appendix for the transcription convention).

\section{Method of Data Analysis}

The data were analyzed using descriptive and quantitative approach. Quantitative approach was used to calculate the occurrences or the frequency of the data which was then presented in a table. Meanwhile, the descriptive approach was employed to explain the types of impoliteness strategies used 
and the function of the most frequently used strategy in Afraid of the Dark Stand-up comedy show.

The data collected were first classified into five main impoliteness strategies proposed by Culpeper (1996); bald on record impoliteness, positive impoliteness, negative impoliteness, sarcasm or mock politeness, and withhold politeness. After presenting the data, one example was taken from each strategy for further analysis. As the second objective was to find the most frequently used strategy, each occurrence of the strategy was calculated. After finding the most frequently used impoliteness strategy, the researchers discovered the purpose based on its context and supporting theories. Then, a conclusion was made after examining and analyzing all the data.

\section{RESULTS AND DISCUSSION}

The analysis suggests that 105 impoliteness strategies are used by Trevor Noah in his show. It is ascertained that he used all types of impoliteness strategies.

Table 1. The frequency and distribution of impoliteness strategies in Afraid of the Dark Stand-up Comedy Show

\begin{tabular}{|c|c|c|c|}
\hline No. & Strategies & Token & $\%$ \\
\hline 1. & Bald on Record & 8 & 7.6 \\
\hline 2. & Positive Impoliteness & 29 & 27.6 \\
\hline 3. & Negative Impoliteness & 42 & 40.0 \\
\hline 4. & Sarcasm Politeness & 22 & 21.0 \\
\hline \multirow[t]{2}{*}{5.} & Withhold Politeness & 4 & 3.8 \\
\hline & Total & 105 & 100 \\
\hline
\end{tabular}

From 105 impoliteness strategies found in Afraid of the Dark, negative impoliteness strategy is the most frequently used strategy in the show, while withhold politeness strategy is the least frequently used strategy.

Negative impoliteness strategy occurs 42 times or with a percentage of $40 \%$ of the data, which places it with the highest percentage. The next strategy which is mostly used is the positive impoliteness. It appears 29 times or with a percentage of $27.6 \%$ of the data followed by sarcasm politeness which occurs 22 times or with a percentage of $21 \%$ of the data. Bald on record impoliteness is used in 8 occurrences with a percentage of $7.6 \%$ of the data. The least strategy used in Afraid of the Dark is withhold politeness which appears 4 times or with a percentage of 3.8\% of the data. Each strategy is discussed in detail below.

\section{Bald on Record Impoliteness}

Bald on record impoliteness strategy is performed in a direct, clear, and concise way in attacking the addressee's face (Culpeper, 1996). In Afraid of the Dark, Trevor Noah uses this strategy to attack the audience's face and the character he plays in order to amuse the audience.

(2) 00:33:35-00:33:45

\section{I don't throw up}

1 TN: If there's one thing you should know about me, it's I don't throw up

2 AU: ((Laughter))

3 TN: I control myself

4 When I see people throwing up, I'm like, "You're weak. Control yourself. You're weak." \{pointing to the audience\}

5 AU: ((Laughter))

In this extract, Trevor talks about his drinking experience. He tells the audience that he does not throw up after having a drink. He then mocks those who throw up after drinking. However, when Trevor says 'people', he orients it to the audience. He also points a finger at them while saying 'you are weak'. His gesture and words are used to attack the audience's face. It is performed directly and clearly to make a judgment of the audience which is categorized as bald on record impoliteness. Nevertheless, the audience responds humorously to the mockery because it is true that people do throw up after excess drinking and are unable to control themselves. This according to Trevor is a sign of weakness.

\section{Positive Impoliteness}

Culpeper (1996) describes positive impoliteness as a strategy which is intended to attack the addressee's positive face. Below is an example.

(3) $\quad 00: 18: 48-00: 19: 11$ 
There is something wrong with the British's skin

1 TN: [You're not feeling too right. I didn't want to say anything, but you look like you're going to faint $]^{\mathrm{IN}}$

2 [In fact, it looks like you have died last week. Okay?] $]^{\text {IN }}$

3 AU: ((Laughter))

4 TN: [Something is very wrong with your skin. You're not looking good. Maybe you should come down. We have a curry, we talk about this] $]^{\mathrm{N}}$

5 AU: ((Laughter))

6 TN: [What are you talking about? I look quite normal!! ${ }^{\mathrm{BR}}$

$7 \quad$ [You do not look normal] $]^{\mathrm{N}}$

8 [I have never seen anybody with that complexion in my life, okay? ${ }^{\text {IN }}$ \{pointing the face\}

9 AU: ((Laughter))

10 TN: [You look like you're playing hide-andseek with the sun your entire life $]^{\mathrm{IN}}$

11 AU: ((Laughter))

12 TN: [I don't know what is happening, but that is not how a person should look $]^{\mathrm{IN}}$

13 AU: ((Laughter))

The example above suggests how impoliteness can inflict attack to the positive face. Trevor Noah gives an account of the British invasion in India. He impersonates an Indian man on seeing an English man for the first time. The Indian man is astonished by the English man's skin color which is unlike his. He compares the English man's skin color to that of a corpse. He further says that the English man has not been exposed to the sun and a person should not be as pale as him. The utterance comes as an insult to the English man's physical appearance and thus is identified as an attack to the positive face This shows that the Indian man disregards the face need of the English man. The attack on the English man's positive face incites the audience's laughter at the expense of the English man.

\section{Negative Impoliteness}

Negative impoliteness is a strategy used by the speaker to damage the addressee's negative face wants. An example of negative impoliteness is shown below.

(4) 00:01:06-00:01:30

\section{New York}

1 TN: New York! New York! Yeah! New York!

2 I'm walking over here!

3 AU: ((laughter))

4 TN: That was all I thought New York was before I came here.

5 I just thought it was a city of people almost getting run over.

6 AU: ((laughter))

7 TN: Just everyone walking into the street, a taxi rolling up, slamming the hood.

[I'm walking over here! What's wrong with you? You want some coffee? $]^{\mathrm{NY}}$

8 AU: ((laughter))

In the example above, Trevor uses negative impoliteness to attack his audience who are mostly New Yorkers by telling about his experience in New York. He says 'I am walking over here' to ridicule them about the occasion of crossing the road and almost getting run over. Trevor's impression and exaggerated portrayal of New York is used to criticize the traffic and ridicule the audience. This act of negative impoliteness does not offend the audience. It makes them laugh in response to the portrayal of the hustle and bustle of New York because it is the fact that New York is a bustling city.

\section{Sarcasm Politeness}

Sarcasm is a face-threatening act that is performed through the employment of politeness strategy insincerely (Culpeper, 1996). Sarcasm is polite on the surface, but it causes an offense. Trevor uses a lot of sarcasm politeness in Afraid of the Dark. The examples and analysis are shown in the following section. 
(5) $\quad 00: 22: 20-00: 22: 29$

\section{Travel to Non-English-speaking Country}

1 TN: I try and do that all the time.

2 I try my utmost.

3 I go to English-speaking countries, but I try every now and again to go to a country where they speak no English.

$4 \quad$ Like, recently, I went to Scotland. Right?

5 AU: ((Laughter))

In this extract, Trevor tells a story about his travel experience. He mentions that occasionally he visits non-English-speaking countries, one of which is Scotland. Trevor uses sarcasm or mock politeness to refer to Scotland. His utterance is incongrous and this induces laughter from the audience. He explains that Scotland is a non-English speaking country because the English spoken by its people does not sound like English. There are many different accents and dialects spoken in the country that makes it incomprehensible for people who are not from Scotland, like Trevor Noah.

\section{Withhold Politeness}

The last strategy stated by Culpeper is withhold politeness. This strategy is used when there is no response from the speaker when politeness expression is expected (Culpeper, 1996). Being silent and failing to thank are examples of this strategy.

\section{(6) $\quad 00: 36: 27-00: 36: 55$}

\section{I need to go to the hospital}

1 TN: [groaning] And then blood came out. Yeah, not good

2 So, I panicked. I was like, I'm bleeding internally. I need to get to the hospital.

3 Called my friend Mick. I was like, "Mick, where are you?"

4 He's like, [I'm home. What's going on?] ${ }^{\mathrm{SC}}$

5 I said, "I need your help. I drank too much last night."

6 He's like, [Yeah. And?] ${ }^{\mathrm{sc}}$
7 I said, "This morning, I threw up a lot."

8 He's like, [Yeah, right. And? ]s

9 AU: ((Laughter))

10 TN: I said, "And then, while I was throwing up, blood came out."

11 He's like, [Yeah, right. And?] ${ }^{\mathrm{sc}}$

12 AU: ((Laughter))

In this example, Trevor tells about his Scottish friend, Mick, who fails to understand him. When Trevor becomes very ill when he is in Scotland, he calls his friend, Mick. He expects that Mick would offer to take him to the hospital but his reaction to Trevor's account of his illness does not conform to politeness. Mick's response by saying "Yeah, right. And?" is categorized as withhold politeness. This suggests that a desired politeness is expected here.

Mick's reaction evokes laughter from the audience because there is a clash of expectations. It is also against the expected politeness norms and social rules. Mick's responses are incongruous to what is expected of him.

In his show, Afraid of the Dark, Trevor Noah uses negative impoliteness strategy as the main purpose to entertain his audience. In general, impoliteness makes people hurt or angry. However, the fact that people can be entertained by impoliteness such as symbolic violations to identity and social rights is not surprising (Culpeper, 2011). This happens because there is a pleasure experienced by people related to impoliteness and entertainment (Culpeper, 2011). The audience find the bits hilarious because they disrupt the expectations of the audience.

To be specific, Trevor frequently uses negative impoliteness sub-strategy of 'condescend, scorn or ridicule'. This show involves a lot of condescending and ridiculing. Condescending happens when Trevor feels smarter or stronger than the audience and ridiculing happens when Trevor makes the audience seem foolish. These sub-strategies are frequently used because hearing one being ridiculed or condescended gives the audience pleasure. Impoliteness is merely used as a device to entertain the audience. 


\section{CONCLUSION}

The research investigates the use of impoliteness strategy in Afraid of the Dark stand-up comedy show performed by Trevor Noah. From the Afraid of the Dark stand-up comedy show, it is found that Trevor Noah uses all types of impoliteness strategies; bald on record impoliteness, positive impoliteness, negative impoliteness, sarcasm or mock politeness, and withhold politeness. From 105 utterances using impoliteness strategies, the negative impoliteness strategy becomes the most frequently used strategy with 42 utterances or $40 \%$ of the data. Then, it is followed by positive impoliteness with 29 utterances (27.6\%), sarcasm politeness with 22 utterances (21\%), bald on record impoliteness with 8 utterances (7.6\%), and withhold politeness with 4 utterances (3.8\%).

As the most frequently used strategy, negative impoliteness is used to produce hilarity to entertain the audience and thus evoke laughter. Trevor mostly used 'condescend, scorn, or ridicule' sub-strategy of negative impoliteness. This strategy is used to give the audience enjoyment of pleasure when hearing one being ridiculed or condescended.

\section{REFERENCES}

Brown, P. \& Levinson, S. C. (1987) Politeness: Some universal in language usage. Cambridge University Press.

Culpeper, J. (1996) Toward an anatomy of impoliteness. Journal of Pragmatics, 25(3), 349-367.

Culpeper, J. (2011). Impoliteness: Using language to cause offence. Full Research Report ESRC End of Award Report, 015, 13-23.

Cutting, J. (2002) Pragmatics and discourse. Routledge.

Editors Biography.com. (2015). Retrived from https://www.biography.com/mediafigure/trevor-noah.

Glick, J. (2007). Some performative techniques of stand-up comedy: An exercise in the textuality of temporalization. Journal of Language \& Communication, 27, 291-306.

Kurniawan, H. (2015). Politeness Strategies in Russell Peters Red, White and Brown Standup Comedy Show. (Unpublished Undergraduate Thesis). Universitas Gadjah Mada, Yogyakarta, Indonesia.

Mirhosseini, M., Mardanshahi, M., \& Dowlatabadi, H. (2017). Impoliteness strategies based on Culpeper's model: An analysis of gender differences between two characters in the movie Mother. Journal of Applied Linguistic and Language Research, 4(3), 221-238.

Rosa, R. (2017). Impoliteness strategies in the Fault in Our Star Film. (Unpublished

Undergraduate Thesis). Universitas Islam Negeri Syarif Hidayatullah, Jakarta, Indonesia.

Schwarz, J. (2010). Linguistic aspect of verbal humor in stand-up comedy. (Unpublished $\mathrm{PhD}$. Dissertation). Saarland University, Saarbrücken, Germany.

Uçar, Aygül \& Yildiz, Ipek. (2015). Humour and impoliteness in Turkish: A corpus-based analysis of the television show Komedi Dükkânı (Comedy Shop). Cambridge Scholar Publishing.

\section{APPENDIX}

Transcription convention

((laughter))

And then he said, "what's wrong?" \{standing ovation\}
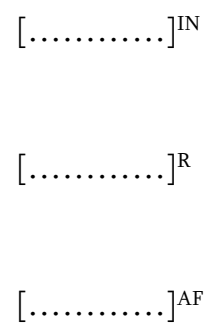

Aspects of utterance, such as whispers, coughing, and laughter, are indicated with double parentheses $((\ldots))$ Quotation marks “ " are given when Trevor is making direct statements.

Nonverbal behavior, such as movements and looks, are indicated with braces $\{\ldots\}$

When Trevor imitates Indian accent the sentence is in square brackets with IN

When Trevor imitates Russian accent the sentence is in square brackets with ${ }^{\mathrm{R}}$

When Trevor imitates African accent the sentence is in square brackets with ${ }^{\mathrm{AF}}$ 
$[\ldots \ldots \ldots \ldots]^{\mathrm{SC}} \quad$ When Trevor imitates Scottish accent the sentence is in square brackets with $\mathrm{SC}$

$[\ldots \ldots \ldots \ldots]^{\mathrm{NM}} \quad$ When Trevor imitates Nelson Mandela's dialect is in square brackets with ${ }^{\mathrm{NM}}$

$[\ldots \ldots \ldots \ldots]^{\mathrm{BR}} \quad$ When Trevor imitates British accent the sentence is in square brackets with ${ }^{B R}$

$[\ldots \ldots \ldots \ldots]^{\mathrm{BO}} \quad$ When Trevor imitates Barrack Obama's way of uttering the sentence is in square brackets with BO

$[\ldots \ldots \ldots \ldots]^{\mathrm{XX}} \quad$ When Trevor acts while uttering the sentence is in square brackets with $\mathrm{xx}$ 